\title{
Decreased expression of the plasminogen activator inhibitor type 1 is involved in degradation of extracellular matrix surrounding cervical cancer stem cells
}

\author{
MASAKAZU SATO, KEI KAWANA, KATSUYUKI ADACHI, ASAHA FUJIMOTO, MITSUYO YOSHIDA, \\ HIROE NAKAMURA, HARUKA NISHIDA, TOMOKO INOUE, AYUMI TAGUCHI, JURI TAKAHASHI, \\ SATOKO KOJIMA, AKI YAMASHITA, KENSUKE TOMIO, TAKESHI NAGAMATSU, \\ OSAMU WADA-HIRAIKE, KATSUTOSHI ODA, YUTAKA OSUGA and TOMOYUKI FUJII \\ Department of Obstetrics and Gynecology, Graduate School of Medicine, The University of Tokyo, \\ Hongo, Bunkyo-ku, Tokyo 113-8655, Japan
}

Received October 16, 2015; Accepted November 22, 2015

DOI: 10.3892/ijo.2015.3283

\begin{abstract}
The plasminogen activator (PA) system consists of plasminogen activator inhibitor type 1 (PAI-1), urokinase-type plasminogen activator and its receptor (uPA and UPAR). PAI-1 inhibits the activation of uPA (which converts plasminogen to plasmin), and is involved in cancer invasion and metastasis, by remodeling the extracellular matrix (ECM) through regulating plasmin. Cancer stem cells (CSCs) are a small subset of cells within tumors, and are thought to be involved in tumor recurrence and metastasis. Considering these facts, we investigated the relationship between PAI-1 and cervical CSCs. We used ALDH1 as a marker of cervical CSCs. First, we demonstrated that culturing ALDH1-high cells and ALDH-low cells on collagen IV-coted plates increased their expression of active PAI-1 (ELISA), and these increases were suggested to be at mRNA expression levels (RT-qPCR). Secondly, we demonstrated PAI-1 was indeed involved in the ECM maintenance. With gelatin zymography assays, we found that ALDH1-high cells and ALDH-low cells expressed pro-matrix metalloproteinase-2 (pro-MMP-2) irrespective of their coatings. With gelatinase/collagenase assay kit, we confirmed that collagenase activity was increased when ALDH1-low cells were exposed to TM5275, a small molecule inhibitor of PAI-1. Putting the data together, we hypothesized that cancer cells adhered to basal membrane secrete abundant PAI-1, on the other hand, cancer cells (especially CSCs rather than non-CSCs) distant from basal membrane secrete less PAI-1, which makes the ECM surrounding CSCs more susceptible to degradation. Our
\end{abstract}

Correspondence to: Dr Kei Kawana, Department of Obstetrics and Gynecology, Graduate School of Medicine, The University of Tokyo, 7-3-1 Hongo, Bunkyo-ku, Tokyo, 113-8655, Japan E-mail:kkawana-tky@umin.org

Key words: cancer stem cells, plasminogen activator inhibitor type 1, extracellular matrix, cervical cancer, aldehyde dehydrogenase 1 study could be an explanation of conflicting reports, where some researchers found negative impacts of PAI-1 expression on clinical outcomes and others not, by considering the concept of CSCs.

\section{Introduction}

The plasminogen activator (PA) system consists of plasminogen activator inhibitor type 1 (PAI-1), urokinase-type plasminogen activator and its receptor (UPA and UPAR) (1). PAI-1 inhibits the activation of uPA (which converts plasminogen to plasmin), and the PA system is involved in proteolysis (1). Dysregulation of the PA system is related to disorders such as thrombosis, atherosclerosis and type 2 diabetes (2-5). In addition, it has been reported that PAI-1 is involved in cancer invasion and metastasis, by remodeling the extracellular matrix (ECM) through regulating plasmin (6-12). Some studies reported that overexpression of PAI-1 correlated with poor prognosis in cancer patients, however, it is controversial (13-16).

Cancer stem cells (CSCs) are a small subset of cells within tumors and possess abilities similar to normal stem cells; the ability to self-renew and differentiate $(17,18)$. This concept was first demonstrated in leukemia and increasing evidence supports this model in various types of solid tumors including cervical cancer (19-24). CSCs are thought to be involved in tumor recurrence and metastasis; failure to treat CSCs by surgery or chemotherapy would result in relapse (17). Considering these facts, investigating the impact of PAI-1 on CSCs could give insight into CSC features in terms of metastasis.

In this study, we investigated the significance of PAI-1 in CSCs and non-CSCs. In cervical cancer, ALDH1-positive cells, like other solid tumors, are known to be more tumorigenic than negative ones, and we used ALDH1 as a marker of cervical CSCs (25-34). First, using the cervical cancer cell line CaSki we confirmed that the expression of PAI-1 was significantly increased by changing coatings of culture plates as described (35), especially collagen IV-coating, confirmed by enzyme-linked immunosorbent assay (ELISA). These results 
were also obtained after sorting CaSki cells into ALDH1-high cells and ALDH1-low cells, and in addition, the expression levels themselves in the supernatants from ALDH1-high cells and ALDH1-low cells were different.

Secondly, we investigated the significance of PAI-1 in degradation of the ECM, by investigating gelatin zymography assays and collagenase activity assays. We found that matrix metalloproteinase-2 (MMP-2) was involved, and confirmed that the activity to degrade the ECM was increased by exposing ALDH1-low cells to TM5275 (a small molecule inhibitor of PAI-1). This result was suggestive that PAI-1 was indeed involved in maintaining the ECM, especially around non-CSCs. In conclusion, we investigated the significance of PAI-1 in CSCs and non-CSCs. The expression levels of PAI-1 were different from ALDH1-high cells to ALDH1-low cells, and also different depending on culture plates. Our study could be an explanation of conflicting reports, where some researchers found the impacts of PAI- 1 expression on poor clinical outcomes and others not, by considering the concept of CSCs.

\section{Materials and methods}

Cell culture. The cervical cancer cell lines CaSki and SiHa were obtained from American Type Culture Collection (ATCC, USA) and cultured in Dulbecco's modified Eagle's medium (DMEM; Wako, Japan) supplemented with 10\% fetal bovine serum (FBS; Invitrogen, Carlsbad, CA, USA) and sub-cultured by $0.25 \%$ trypsin/EDTA (Wako) detachment. The cells were grown in a humidified atmosphere at $37^{\circ} \mathrm{C}$ and $5 \% \mathrm{CO}_{2}$.

Coatings. Fibronectin solution, vitronectin solution and laminin solution were purchased from Wako (Cat\# 063-05591, 220-02041 and 120-05751, respectively), and were used according to manufacturer's instructions. Collagen I and collagen IV-coated plates were obtained from Corning (Acton, MA, USA).

Reagents. Human PAI-1 peptide was purchased from Abcam (Cambridge, MA, USA). TM5275 was purchased from Axon Medchem (USA).

RNA extraction and RT-quantitative PCR (RT-qPCR). Total RNA was extracted with Tissue Total RNA kit (Favorgen Biotech Corp., Taiwan) according to manufacturer's protocols. First-strand cDNA was synthesized from 500 ng of total RNA using ReverTra Ace (Toyobo, Japan). qPCR was performed with SYBR Green PCR master mix (Roche) according to manufacturer's instructions. Denaturation was performed at $95^{\circ} \mathrm{C}$ for $2 \mathrm{~min}$, followed by 35 cycles at $98^{\circ} \mathrm{C}$ for $10 \mathrm{sec}$, at $65^{\circ} \mathrm{C}$ for $10 \mathrm{sec}$ and at $68^{\circ} \mathrm{C}$ for $10 \mathrm{sec} . \beta$-actin was used as a housekeeping gene and the results are presented as fold change relative to $\beta$-actin expression $\left(2^{-\Delta \Delta C t}\right)$. Each experiment was performed in triplicate. The sequences of the primer pairs used in this study are shown in Table I.

Enzyme-linked immunosorbent assay (ELISA). Culture supernatants were assayed for active PAI-1 and active uPA by ELISA kits (Innovation Research Inc., USA, Cat\# IHPAIKT and IHUPAKT) according to manufacturer's protocol. Cells
Table I. Primer sequences used in this study.

\begin{tabular}{|c|c|c|}
\hline Gene name & Primer sequence & Size (bp) \\
\hline PAI-1 & $\begin{array}{l}\text { GCACCACAGACGCGATCTT } \\
\text { ACCTCTGAAAAGTCCACTTGC }\end{array}$ & 112 \\
\hline uPA & $\begin{array}{l}\text { GCCATCCCGGACTATACAGA } \\
\text { AGGCCATTCTCTTCCTTGGT }\end{array}$ & 417 \\
\hline uPAR & $\begin{array}{l}\text { CTGGAGCTGGTGGAGAAAAG } \\
\text { TGTTGCAGCATTTCAGGAAG }\end{array}$ & 406 \\
\hline$\beta$-actin & $\begin{array}{l}\text { CATGTACGTTGCTATCCAGGC } \\
\text { CTCCTTAATGTCACGCACGAT }\end{array}$ & 250 \\
\hline
\end{tabular}

Gene names and primer sequences (5'-3') for RT-PCR and qPCR are shown. PAI-1, plasminogen activator inhibitor type 1; uPA, urokinase-type plasminogen activator; uPAR, urokinase-type plasminogen activator receptor.

$\left(2 \times 10^{5}\right)$ were seeded into 6 -well plates and were cultured for $24 \mathrm{~h}$. After that, medium was switched to DMEM without FBS for $24 \mathrm{~h}$, and then the supernatants were collected. Immediately after collection, these supernatants were centrifuged for $10 \mathrm{~min}$ at $300 \mathrm{x} \mathrm{g}$ to remove cell debris and were stored at $-80^{\circ} \mathrm{C}$. For detection of intracellular active PAI-1, cells were permeabilized with $1 \mathrm{ml}$ of $0.5 \%$ Triton X-100 for $20 \mathrm{~min}$. Plates were read on an ELISA reader, EPOCH (BioTek, Winooski, VT, USA).

Flow cytometry. The ALDH enzymatic activity of the cells was measured as described previously (34), using the Aldefluor kit (StemCell Technologies, Vancouver, BC, Canada). CaSki cells $\left(5 \times 10^{6}\right.$ cells) were suspended in Aldefluor assay buffer containing ALDH substrate. The brightly fluorescent ALDHpositive cells were detected using MoFlo XDP (Beckman Coulter, Inc., Brea, CA, USA). As a negative control, cells were stained under identical conditions after treatment with the specific ALDH inhibitor N,N-diethylaminobenzaldehyde (DEAB). After sorting, $1 \times 10^{5}$ cells were seeded into 6-well plates and were cultured for $24 \mathrm{~h}$. Then medium was changed under each experimental condition. Experiment was repeated at least three times.

Gelatin zymograhpy assays. Gelatin zymography assays (Cosmobio, Japan, Cat\# AK45) were performed as previously described (36). Collected supernatants $(10 \mu \mathrm{l})$ were mixed with $2 \mathrm{X}$ sample buffer and electrophoresed according to manufacturer's instructions. Subsequent enzymatic reactions were performed at $37^{\circ} \mathrm{C}$ for $40 \mathrm{~h}$.

Collagenase activity assays. Collagenase activity was detected with EnzChek Gelatinase/Collagenase Assay kit (Molecular Probes, USA, Cat\# E-12055) according to manufacturer's instructions. The supernatant $(100 \mu \mathrm{l})$ was used, and incubated with DQ gelatin solution for $24 \mathrm{~h}$ at room temperature. The fluorescence intensity was measured in a fluorescence microplate reader, Fluoroskan Ascent FL (Thermo Fisher Scientific, Waltham, MA, USA), set for excitation at $485 \mathrm{~nm}$ 
A

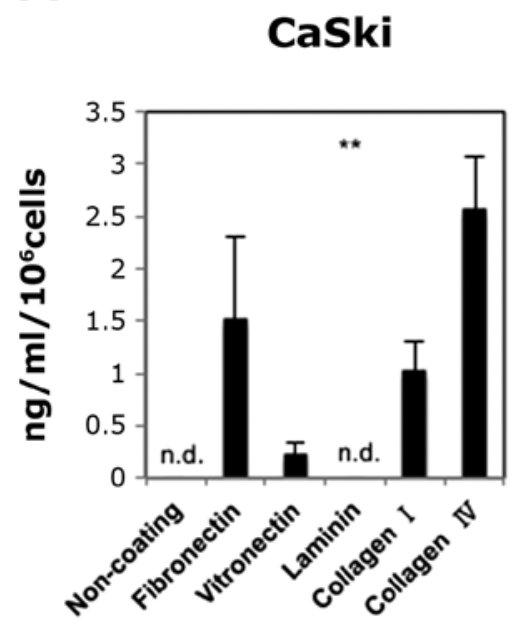

SiHa

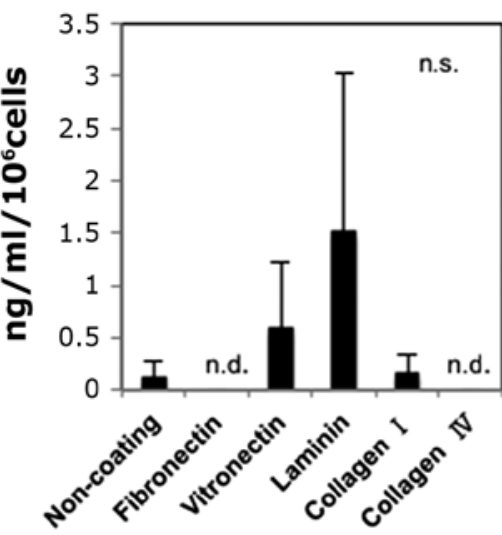

B

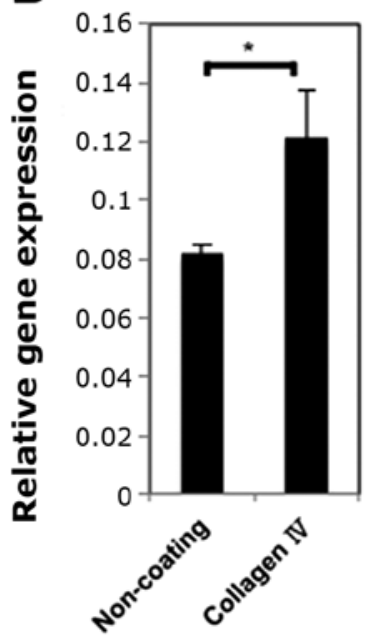

Figure 1. Influence of types of coatings on PAI-1 expression. (A) Influence of types of coatings on active PAI-1 expression in the supernatants from CaSki and SiHa. Active PAI-1 levels in the supernatants from CaSki were significantly increased (ELISA). Experiments were performed in duplicate and repeated three times $(n=3)$. The values shown represent the mean \pm SE. (B) Influence of collagen IV on PAI-1 mRNA expression of CaSki. Culturing CaSki cells on collagen IV-coted plates increased their expression levels of PAI-1 mRNA (RT-qPCR). Experiments were performed in triplicate and repeated three times $(\mathrm{n}=3)$. The values shown represent the mean $\pm \mathrm{SE}$. ${ }^{* *} \mathrm{p}<0.01,{ }^{*} \mathrm{p}<0.05$; n.s., not significant. n.d., not detected. (A) X-axis, non-coating, fibronectin, vitronectin, laminin, collagen I or collagen IV. Y-axis, $\mathrm{ng} / \mathrm{ml} / 10^{6}$ cells. (B) X-axis, non-coating or collagen IV. Y-axis, relative gene expression.

and emission detection at $538 \mathrm{~nm}$. The fluorescence intensity was corrected for background fluorescence by subtracting the value derived from the no-enzyme control. Clostridium collagenase (provided with the kit) was used as a positive control. Experiment was repeated three times.

Statistical analysis. ANOVA test was used for comparing the influence of the ECM. Student t-test was used to compare the means of expression levels of PAI-1. Wilcoxon rank-sum test was used to investigate the effects of TM5275. p-values $<0.05$ were considered statistically significant. JMP/SAS Institute software was used for statistical analysis.

\section{Results}

Expression levels of PAI-1 are significantly different depending on the coating. In advance, we confirmed the expression of PAI-1, uPA and UPAR of CaSki and SiHa by RT-PCR (data not shown). The concentration of active PAI-1 in the supernatants from CaSki and SiHa is shown in Fig. 1A. The expression levels of active PAI- 1 in the supernatants from CaSki cells were significantly different depending on the coating, and we selected CaSki cells for further experiment. Besides, we decided to investigate the relationship between collagen IV and PAI-1, because i) We detected high levels of PAI-1 when culturing CaSki cells on collagen IV-coated plates as shown in Fig. 1A. ii) Few studies have investigated the relationship between PAI-1 and collagen IV, while most studies investigated the relationship between PAI-1 and fibronectin, vitronectin and laminin $(1,8,11,35)$. iii) Collagen IV is known to be rich in basal membrane (where cervical cancer occurs) (37), and collagen IV could be important for CSCs. As shown in Fig. 1B, culturing CaSki cells on collagen IV-coated plates increased the expression of PAI-1 at mRNA levels.
Expression levels of PAI-1 are different from ALDH1-high cells to ALDH1-low cells. We performed the same procedures after sorting CaSki cells into ALDH1-high cells and ALDH1-low cells. As shown in Fig. 2A, culturing ALDH1high cells and ALDH1-low cells on collagen IV-coated plates increased the expression levels of PAI-1 mRNA. The increase of ALDH1-high cells was statistically significant, and it was suggestive that ALDH1-high cells contributed to the increase of PAI-1 mRNA expression levels (Fig. 1A).

PAI-1 plays a role in maintaining the ECM when secreted (1), and we detected secreted active PAI-1 in the supernatants of cultured cells using ELISA. In addition, since the balance of UPA and PAI-1 is important rather than the concentration of PAI-1 itself $(1,2,15)$, we investigated secreted active uPA as well (Fig. 2B). We found that the expression of PAI-1 is higher when cells were cultured on collagen IV-coated plates than when cultured on non-coating plates, and that the expression of PAI-1 of ALDH1-low cells was higher than that of ALDH1high cells.

Of note, the patterns of secreted PAI-1 and PAI-1 mRNA expression levels were apparently different. In the context of maintaining the ECM, not only active PAI-1 but also many factors, such as non-active PAI-1, uPA, tPA and UPAR, and their combination are important $(1,7,10,15,38-40)$. Considering these facts, the expression levels of PAI-1 mRNA do not have to accord with the concentration of secreted active PAI-1, however, we further detected intracellular active PAI-1 in order to obtain insights into the inconsistency. Of interest, the concentration of intracellular active PAI-1 was similar to the expression patterns of PAI-1 mRNA (Fig. 2A and C). These results can be interpreted as follows: The amount of active PAI-1 is consistent with the expression of PAI-1 mRNA, however, PAI-1 from ALDH1-high cells is more difficult to be secreted than PAI-1 from ALDH1-low cells [due to transportation system or membrane permiability, for instance (41)]. 
A

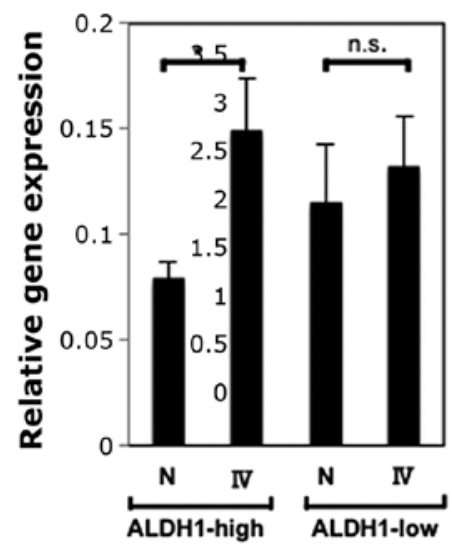

B

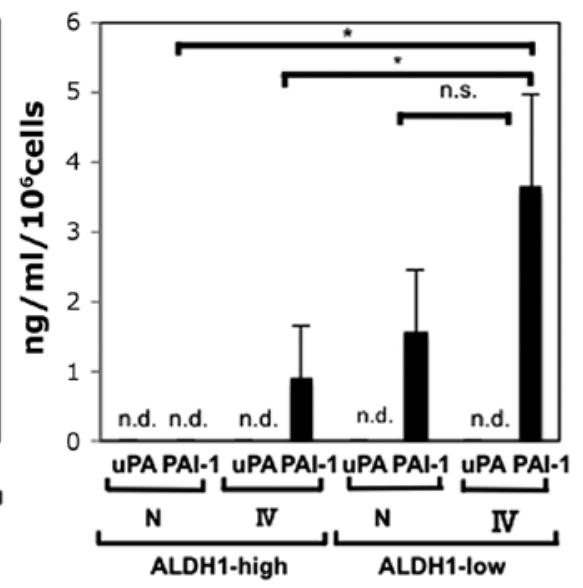

C

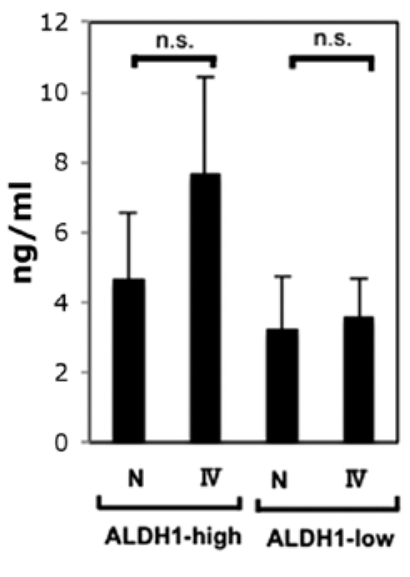

Figure 2. Influence of collagen IV on PAI-1 expression of ALDH1-high cells and ALDH1-low cells. (A) Influence of collagen IV on PAI-1 mRNA expression of ALDH1-high cells and ALDH1-low cells. Culturing ALDH1-high cells on collagen IV-coted plates significantly increased their expression levels of PAI-1 mRNA (RT-qPCR). Experiments were performed in triplicate and repeated four times ( $=4$ ). The values shown represent the mean \pm SE. (B) Influence of collagen IV on active uPA and active PAI-1 levels in the supernatants from ALDH1-high cells and ALDH1-low cells. Culturing ALDH1-high cells and ALDH1-low cells on collagen IV-coted plates increased their expression of active PAI-1 (ELISA). The expression levels of PAI-1 in the supernatants from ALDH1-low cells cultured on collagen IV-coted plates were significantly higher than those from ALDH1-high cells cultured on both non-coating and collagen IV-coated plates. Experiments were performed in duplicate and repeated six times $(n=6)$. The values shown represent the mean \pm SE. (C) Influence of collagen IV on intracellular active PAI-1 levels in ALDH1-high cells and ALDH1-low cells. The patterns of intracellular active PAI-1 levels (ELISA) were similar to the patterns of PAI-1 mRNA expression levels (A). Experiments were performed in duplicate and repeated three times (n=3). The values shown represent the mean \pm SE. " p<0.05, n.s.; not significant. n.d.; not detected, N; non-coating, IV; collagen IV. (A) X-axis: ALDH1-high or ALDH1-low and N or IV. Y-axis, relative gene expression. (B) X-axis, ALDH1-high or ALDH1-low, N or IV and uPA or PAI-1. Y-axis: ng/ml/10 6 cells. (C) X-axis, ALDH1-high or ALDH1-low and $\mathrm{N}$ or IV. Y-axis, ng/ml.

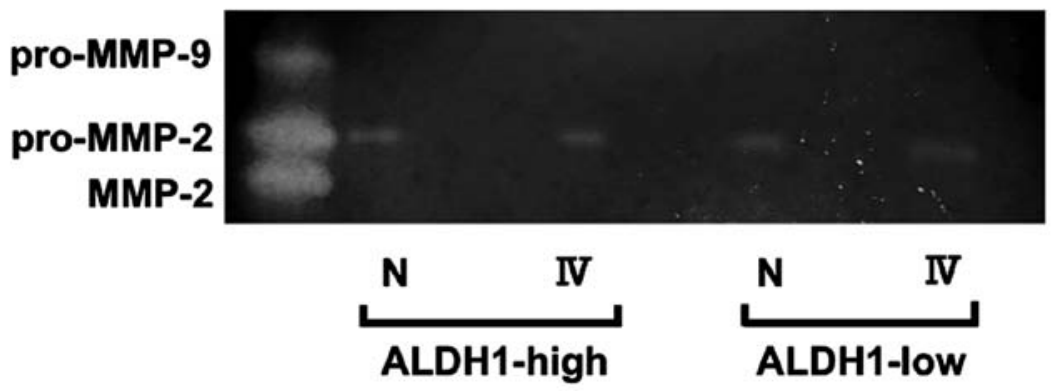

Figure 3. Results of gelatin zymography assays. Each supernatant expressed only pro-MMP-2. Representative data are shown. Experiments were performed three times. MMP, matrix metalloproteinase; N, non-coating; IV, collagen IV. X-axis, ALDH1-high or ALDH1-low and N or IV. Y-axis, MMP-2, pro-MMP-2 or pro-MMP-9.

ALDH1-high cells and ALDH1-low cells express pro-MMP-2. We then speculated on the impact of PAI-1 in maintenance of the ECM. With gelatin zymography assays, we investing the ability of each collected supernatant to degrade the general ECM, gelatin. As shown in Fig. 3, each supernatant expressed only pro-MMP2. This result was acceptable since pro-MMP-2 is the substrate of plasmin $(1,42)$, although we could not find significant difference of pro-MMP-2 expression among these conditions.

Exposing ALDH1-low cells to TM5275, a small molecule inhibitor of PAI-1, increases collagenase activity of the supernatants. In order to quantify the activity of degrading the ECM, we proceeded to perform collagenase activity assays. After sorting, $1 \times 10^{5}$ cells were seeded and cultured for $24 \mathrm{~h}$. Then, medium was changed to DMEM with or without $10 \mathrm{nM}$ TM5275 for $24 \mathrm{~h}$, and the supernatants were collected (43). As shown in Fig. 4, collagenase activity was increased only when ALDH1-low cells were exposed to TM5275. The intensities ranged from the intensity of $0.02 \mathrm{U} /$ $\mathrm{ml}$ of clostridium collagenase to that of $0.2 \mathrm{U} / \mathrm{ml}$ of clostridium collagenase.

\section{Discussion}

In the present study, we investigated the significance of PAI-1 in cervical CSCs and non-CSCs, and its impact on the ECM maintenance. PAI-1 inhibits the activation of uPA (which converts plasminogen to plasmin), and it is involved in cancer invasion and metastasis, by remodeling the ECM through regulating plasmin (1,6-12). The studies investigating CSCs are now increasing in various types of solid tumors including cervical cancer, and CSCs are thought to be involved in tumor recurrence and metastasis $(17,18)$. Putting these facts together, 


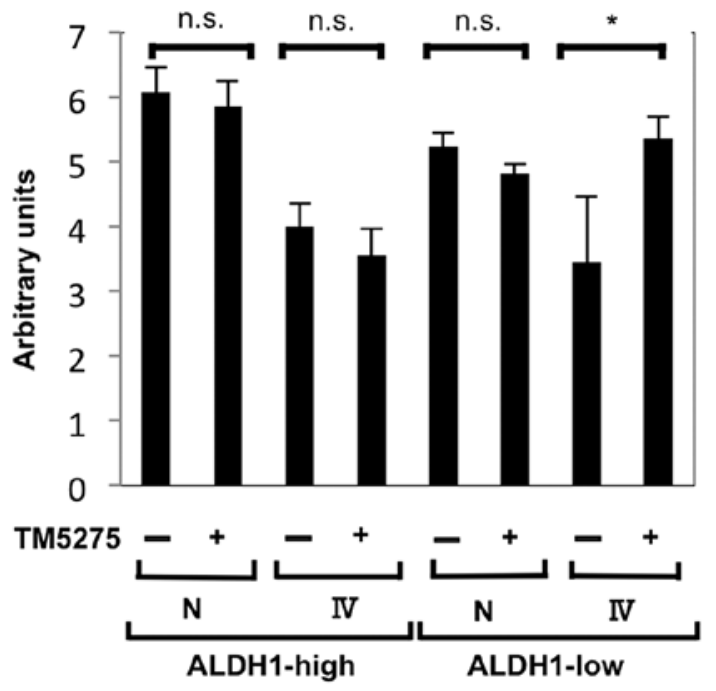

Figure 4. Effects of TM5275, a small molecule inhibitor of PAI-1, on collagenase activity. Collagenase activity was significantly increased only when ALDH1-low cells were exposed to $10 \mathrm{nM}$ TM5275 (Wilcoxon rank-sum test). These intensities were ranged from the intensity of $0.02 \mathrm{U} / \mathrm{ml}$ of clostridium collagenase to that of $0.2 \mathrm{U} / \mathrm{ml}$ of clostridium collagenase (positive control). Experiments were performed in duplicate and repeated three times $(\mathrm{n}=3)$. The values shown represent the mean $\pm \mathrm{SE}$. ${ }^{*} \mathrm{p}<0.05$; n.s., not significant; $\mathrm{N}$, non-coating; IV, collagen IV. X-axis, ALDH1-high or ALDH1-low, $\mathrm{N}$ or IV and TM5275 - or +, Y-axis, arbitrary units.

we aimed to investigate the relationship between PAI-1 and cervical CSCs.

First, using the cervical cancer cell line CaSki we confirmed that the expression levels of PAI-1 were significantly increased when the cells were cultured on collagen IV-coated plates compared to when cultured on non-coated plates, employing ELISA and RT-qPCR. When we use collagen IV as the representative of the ECM, we can put a focus on proteolytic activity of PAI-1 unlike using fibronectin and vitrinectin (nonproteolytic, or direct interaction between PAI-1 and the ECM is known) (1). At the same time, we have to consider the protein downstream of uPA and plasmin such as MMP-2, because the substrate of uPA itself is not collagen IV but fibronectin (44). This is why we performed gelatin zymography assays. With gelatin zymography assays, we found the involvement of pro-MMP-2.

Secondly, we investigated the significance of PAI-1 in maintenance of the ECM, by investigating collagenase activity. We confirmed that the activity to degrade the ECM was increased by exposing ALDH1-low cells to TM5275 (a small molecule inhibitor of PAI-1). On the contrary, adding recombinant PAI-1 (the final concentration of $1 \mu \mathrm{g} / \mathrm{ml}$ ), to the supernatants from ALDH1-high cells cultured on noncoating plates, reduced its fluorescence intensity by $7 \%$ (data not shown). These results were suggestive that PAI-1 was indeed involved in maintaining the ECM in CSCs and nonCSCs.

The limitation of our experiment is that we could not assess to what extent PAI-1 was involved in maintaining the ECM. The question remains from that we could not show a clear inverse correlation between concentration of PAI-1 and fluorescence intensity (Figs. 2B and 3). This is due to the complexity of the PA system, and considering only PAI-1 would not be enough

\section{Hypothesis}

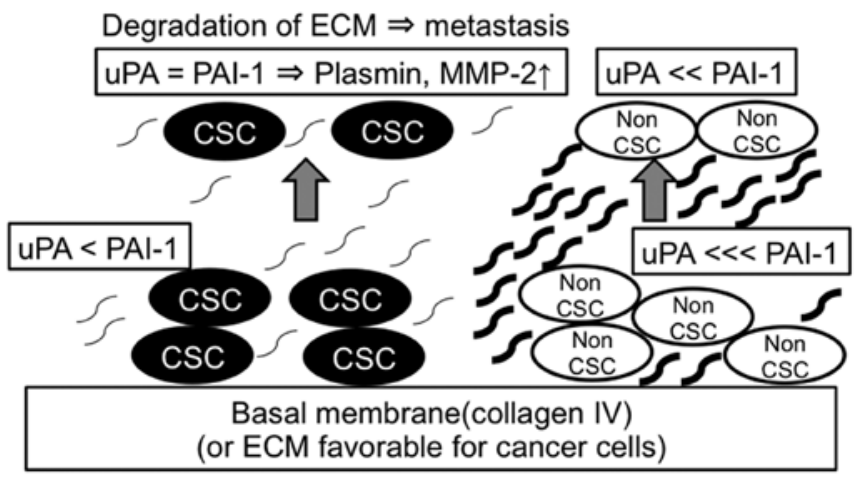

Figure 5. Hypothetic schema from the data we obtained. Cancer cells adhered to basal membrane secrete abundant PAI-1, whereas, cancer cells distant from basal membrane secrete less PAI-1. The concentration of active PAI-1 around CSCs is lower than that around non-CSCs, and the ECM surrounding CSCs is more susceptible to degradation.

in the context of degradation of the ECM (10). However, we may say that we shed light on the necessity to consider the concept of CSCs when investigating the PA system.

ALDH1-low cells expressed PAI-1 more highly than ALDH1-high cells (Fig. 2A). PAI-1 is known to be related to senescence, and it is more highly expressed in 'old cells' than in 'young cells', and 'more passaged cell line' than 'less passaged cell line' (45-47). Considering the direction of differentiation from ALDH1-high cells to ALDH1-low cells, it is reasonable to think that ALDH1-low cells express PAI-1 more highly than ALDH1-high cells.

Although the increase of PAI-1 expression in the supernatants from SiHa cells when cultured on laminin-coated plates was not statistically significant (Fig. 1A), it is suggestive that PAI-1 is important for the interaction between cancer cells and basal membrane, considering that laminin is a major component of basal membrane of uterine cervix as well as collagen IV (37).

In conclusion, we investigated the significance of PAI-1 in CSCs and non-CSCs. The expression levels of PAI-1 of ALDH1-high and ALDH1-low cells were both increased when cultured on collagen IV-coated plates, however, the basic expression levels of PAI-1 of ALDH1-high were lower than those in ALDH1-low cells. This result was suggestive that the ECM surrounding CSCs (especially distant from basal membrane) is more susceptible to degrade due to its low expression levels of PAI-1 (hypothetic schema from the data we obtained is shown in Fig. 5). Although verification to other kinds of CSC markers, and other types of cancers are needed, our study could be an explanation of conflicting reports, where some researchers found negative impacts of PAI-1 expression on clinical outcomes and others not, by considering the concept of CSCs.

\section{Acknowledgements}

We are grateful to Stem Cell Laboratory of Medical Research Institute in Tokyo Medical and Dental University, for kind assistance in flow cytometric sorting. 


\section{References}

1. Czekay RP, Wilkins-Port CE, Higgins SP, Freytag J, Overstreet JM, Klein RM, Higgins CE, Samarakoon R and Higgins PJ: PAI-1: An integrator of cell signaling and migration. Int J Cell Biol 2011: 562481, 2011.

2. Jankun J: Plasminogen activator inhibitor-1 in kidney pathology (Review). Int J Mol Med 31: 503-510, 2013.

3. Klinger KW, Winqvist R, Riccio A, Andreasen PA, Sartorio R, Nielsen LS, Stuart N, Stanislovitis P, Watkins P, Douglas R, et al: Plasminogen activator inhibitor type 1 gene is located at region q21.3-q22 of chromosome 7 and genetically linked with cysticfibrosis. Proc Natl Acad Sci USA 84: 8548-8552, 1987.

4. Krause MP, Moradi J, Nissar AA, Riddell MC and Hawke TJ: Inhibition of plasminogen activator inhibitor-1 restores skeletal muscle regeneration in untreated type 1 diabetic mice. Diabetes 60: 1964-1972, 2011.

5. Ricart JM, Ramón LA, Vayá A, España F, Santaolaria ML, Todolí J, Castelló R, Fontcuberta J and Estellés A: Fibrinolytic inhibitor levels and polymorphisms in Behcet disease and their association with thrombosis. Br J Haematol 141: 716-719, 2008.

6. Bajou K, Noël A, Gerard RD, Masson V, Brunner N, HolstHansen C, Skobe M, Fusenig NE, Carmeliet P, Collen D, et al: Absence of host plasminogen activator inhibitor 1 prevents cancer invasion and vascularization. Nat Med 4: 923-928, 1998.

7. Fabre-Guillevin E, Malo M, Cartier-Michaud A, Peinado H, Moreno-Bueno G, Vallée B, Lawrence DA, Palacios J, Cano A, Barlovatz-Meimon G, et al: PAI-1 and functional blockade of SNAI1 in breast cancer cell migration. Breast Cancer Res 10: R100, 2008.

8. Smit JW, van der Pluijm G, Romijn HA, Löwik CW, Morreau H and Goslings BM: Degradation of extracellular matrix by metastatic follicular thyroid carcinoma cell lines: role of the plasmin activation system. Thyroid 9: 913-919, 1999.

9. Maillard C, Jost M, Rømer MU, Brunner N, Houard X, Lejeune A, Munaut C, Bajou K, Melen L, Dano K, et al: Host plasminogen activator inhibitor-1 promotes human skin carcinoma progression in a stage-dependent manner. Neoplasia 7: 57-66, 2005.

10. Riddick AC, Shukla CJ, Pennington CJ, Bass R, Nuttall RK, Hogan A, Sethia KK, Ellis V, Collins AT, Maitland NJ, et al: Identification of degradome components associated with prostate cancer progression by expression analysis of human prostatic tissues. Br J Cancer 92: 2171-2180, 2005.

11. Vial D and McKeown-Longo PJ: PAI1 stimulates assembly of the fibronectin matrix in osteosarcoma cells through crosstalk between the alphavbeta5 and alpha5beta1 integrins. J Cell Sci 121: 1661-1670, 2008.

12. Woo M, Park K, Nam J and Kim JC: Clinical implications of matrix metalloproteinase-1, $-3,-7,-9,-12$, and plasminogen activator inhibitor-1 gene polymorphisms in colorectal cancer. J Gastroenterol Hepatol 22: 1064-1070, 2007.

13. Hanekom GS, Stubbings HM and Kidson SH: The active fraction of plasmatic plasminogen activator inhibitor type 1 as a possible indicator of increased risk for metastatic melanoma. Cancer Detect Prev 26: 50-59, 2002.

14. Lara PC, Lloret M, Valenciano A, Clavo B, Pinar B, Rey A and Henríquez-Hernández LA: Plasminogen activator inhibitor-1 (PAI-1) expression in relation to hypoxia and oncoproteins in clinical cervical tumors. Strahlenther Onkol 188: 1139-1145, 2012.

15. Malinowsky K, Wolff C, Berg D, Schuster T, Walch A, Bronger H, Mannsperger H, Schmidt C, Korf U, Höfler $\mathrm{H}$, et al: uPA and PAI-1-related signaling pathways differ between primary breast cancers and lymph node metastases. Transl Oncol 5: 98-104, 2012.

16. Sternlicht MD, Dunning AM, Moore DH, Pharoah PD, Ginzinger DG, Chin K, Gray JW, Waldman FM, Ponder BA and Werb Z: Prognostic value of PAI1 in invasive breast cancer: evidence that tumor-specific factors are more important than genetic variation in regulating PAI1 expression. Cancer Epidemiol Biomarkers Prev 15: 2107-2114, 2006.

17. Meacham CE and Morrison SJ: Tumour heterogeneity and cancer cell plasticity. Nature 501: 328-337, 2013.

18. Reya T, Morrison SJ, Clarke MF and Weissman IL: Stem cells, cancer, and cancer stem cells. Nature 414: 105-111, 2001.

19. Chen X, Rycaj K, Liu X and Tang DG: New insights into prostate cancer stem cells. Cell Cycle 12: 579-586, 2013.

20. Dick JE: Stem cell concepts renew cancer research. Blood 112: 4793-4807, 2008.
21. López J, Valdez-Morales FJ, Benítez-Bribiesca L, Cerbón M and Carrancá AG: Normal and cancer stem cells of the human female reproductive system. Reprod Biol Endocrinol 11: 53, 2013.

22. Skibinski A and Kuperwasser C: The origin of breast tumor heterogeneity. Oncogene 34: 5309-5316, 2015.

23. Triscott J, Rose Pambid M and Dunn SE: Concise review: bullseye: targeting cancer stem cells to improve the treatment of gliomas by repurposing disulfiram. Stem Cells 33: 1042-1046, 2015.

24. Zeki SS, Graham TA and Wright NA: Stem cells and their implications for colorectal cancer. Nat Rev Gastroenterol Hepatol 8: 90-100, 2011.

25. Hirata N, Yamada S, Shoda T, Kurihara M, Sekino Y and Kanda Y: Sphingosine-1-phosphate promotes expansion of cancer stem cells via S1PR3 by a ligand-independent Notch activation. Nat Commun 5: 4806, 2014.

26. Alonso-Alconada L, Muinelo-Romay L, Madissoo K, Diaz-Lopez A, Krakstad C, Trovik J, Wik E, Hapangama D, Coenegrachts L, Cano A, et al: Molecular profiling of circulating tumor cells links plasticity to the metastatic process in endometrial cancer. Mol Cancer 13: 223, 2014.

27. Ma I and Allan AL: The role of human aldehyde dehydrogenase in normal and cancer stem cells. Stem Cell Rev 7: 292-306, 2011.

28. Penumatsa K, Edassery SL, Barua A, Bradaric MJ and Luborsky JL: Differential expression of aldehyde dehydrogenase 1a1 (ALDH1) in normal ovary and serous ovarian tumors. J Ovarian Res 3: 28, 2010.

29. Pisanu ME, Noto A, De Vitis C, Masiello MG, Coluccia P, Proietti S, Giovagnoli MR, Ricci A, Giarnieri E, Cucina A, et al. Lung cancer stem cell lose their stemness default state after exposure to microgravity. Biomed Res Int 2014: 470253, 2014.

30. Pors K and Moreb JS: Aldehyde dehydrogenases in cancer: An opportunity for biomarker and drug development? Drug Discov Today 19: 1953-1963, 2014.

31. Raha D, Wilson TR, Peng J, Peterson D, Yue P, Evangelista M, Wilson C, Merchant M and Settleman J: The cancer stem cell marker aldehyde dehydrogenase is required to maintain a drugtolerant tumor cell subpopulation. Cancer Res 74: 3579-3590, 2014.

32. Warrier S, Bhuvanalakshmi G, Arfuso F, Rajan G, Millward M and Dharmarajan A: Cancer stem-like cells from head and neck cancers are chemosensitized by the Wnt antagonist, sFRP4, by inducing apoptosis, decreasing stemness, drug resistance and epithelial to mesenchymal transition. Cancer Gene Ther 21: 381-388, 2014.

33. Watanabe Y, Yoshimura K, Yoshikawa K, Tsunedomi R, Shindo Y, Matsukuma S, Maeda N, Kanekiyo S, Suzuki N, Kuramasu A, et al: A stem cell medium containing neural stimulating factor induces a pancreatic cancer stem-like cell-enriched population. Int J Oncol 45: 1857-1866, 2014.

34. Liu SY and Zheng PS. High aldehyde dehydrogenase activity identifies cancer stem cells in human cervical cancer. Oncotarget 4: 2462-2475, 2013.

35. Isogai C, Laug WE, Shimada H, Declerck PJ, Stins MF, Durden DL, Erdreich-Epstein A and DeClerck YA: Plasminogen activator inhibitor-1 promotes angiogenesis by stimulating endothelial cell migration toward fibronectin. Cancer Res 61: 5587-5594, 2001.

36. Taguchi A, Kawana K, Tomio K, Yamashita A, Isobe Y, Nagasaka K, Koga K, Inoue T, Nishida H, Kojima S, et al: Matrix metalloproteinase (MMP)-9 in cancer-associated fibroblasts (CAFs) is suppressed by omega-3 polyunsaturated fatty acids in vitro and in vivo. PLoS One 9: e89605, 2014.

37. Goldberg I, Davidson B, Lerner-Geva L, Gotlieb WH, Ben-Baruch G, Novikov I and Kopolovic J: Expression of extracellular matrix proteins in cervical squamous cell carcinoma - a clinicopathological study. J Clin Pathol 51: 781-785, 1998.

38. Han B, Nakamura M, Zhou G, Ishii A, Nakamura A, Bai Y, Mori I and Kakudo K: Calcitonin inhibits invasion of breast cancer cells: Involvement of urokinase-type plasminogen activator (uPA) and uPA receptor. Int J Oncol 28: 807-814, 2006.

39. Hildenbrand R and Schaaf A: The urokinase-system in tumor tissue stroma of the breast and breast cancer cell invasion. Int J Oncol 34: 15-23, 2009.

40. Roomi MW, Kalinovsky T, Niedzwiecki A and Rath M: Modulation of uPA, MMPs and their inhibitors by a novel nutrient mixture in human glioblastoma cell lines. Int J Oncol 45: 887-894, 2014.

41. Chung CL, Sheu JR, Liu HE, Chang SC, Chou YC, Chen WL, Chou DS and Hsiao G: Dynasore, a dynamin inhibitor, induces PAI-1 expression in MeT-5A human pleural mesothelial cells. Am J Respir Cell Mol Biol 40: 692-700, 2009. 
42. Baramova EN, Bajou K, Remacle A, L'Hoir C, Krell HW, Weidle UH, Noel A and Foidart JM: Involvement of PA/plasmin system in the processing of pro-MMP-9 and in the second step of pro-MMP-2 activation. FEBS Lett 405: 157-162, 1997.

43. Izuhara Y, Yamaoka N, Kodama H, Dan T, Takizawa S, Hirayama N, Meguro K, van Ypersele de Strihou C and Miyata T: A novel inhibitor of plasminogen activator inhibitor-1 provides antithrombotic benefits devoid of bleeding effect in nonhuman primates. J Cereb Blood Flow Metab 30: 904-912, 2010.

44. Marchina E and Barlati S: Degradation of human plasma and extracellular matrix fibronectin by tissue type plasminogen activator and urokinase. Int J Biochem Cell Biol 28: 1141-1150, 1996.
45. Ota H, Akishita M, Eto M, Iijima K, Kaneki M and Ouchi Y: Sirt1 modulates premature senescence-like phenotype in human endothelial cells. J Mol Cell Cardiol 43: 571-579, 2007.

46. Calvanese V, Lara E, Suárez-Alvarez B, Abu Dawud R, VázquezChantada M, Martínez-Chantar ML, Embade N, López-Nieva P, Horrillo A, Hmadcha A, et al: Sirtuin 1 regulation of developmental genes during differentiation of stem cells. Proc Natl Acad Sci USA 107: 13736-13741, 2010.

47. Wan YZ, Gao P, Zhou S, Zhang ZQ, Hao DL, Lian LS, Li YJ, Chen HZ and Liu DP: SIRT1-mediated epigenetic downregulation of plasminogen activator inhibitor-1 prevents vascular endothelial replicative senescence. Aging Cell 13: 890-899, 2014. 